\title{
The Digital Economic Literacy of Entrepreneurs Managing Small and Medium Enterprises in the Era of Industrial Revolution 4.0
}

\author{
Dewi Kusuma Wardani, Baedhowi, Laurensia Claudia Pratomo, Andryas \\ Dewi Pratiwi
}

Faculty of Teacher Training and Education of Sebelas Maret University, Indonesia

Received: 27 Sept 2020; Received in revised form: 7 Nov 2020; Accepted: 11 Nov 2020; Available online: 26 Nov 2020 C2020 The Author(s). Published by Infogain Publication. This is an open access article under the CC BY license (https://creativecommons.org/licenses/by/4.0/).

\begin{abstract}
This research aims to identify the economic literacy of entrepreneurs managing small and medium enterprises (UMKM) by analyzing the influence of connectivity, technological advances, users, knowledge of economy, and innovation on digitalization. Quantitative method comprising questionnaire as its sampling technique was employed. The samples in this research were 120 small and medium enterprises. The data collected through questionnaire were analyzed by using Partial Least Square (PLS) analysis. Based on the research findings, both connectivity and users positively and significantly influence digitalization. Meanwhile, technological advances, knowledge of economy, and innovation positively but insignificantly influence small and medium enterprises digitalization. The researchers suggest other researchers to develop certain design or model that nurture and improve the economic literacy of entrepreneurs managing small and medium enterprises.
\end{abstract}

Keywords_digitalization; small and medium enterprises; SMEs; industrial revolution 4.0.

\section{INTRODUCTION}

World economic development nowadays has been entering the era of industrial revolution 4.0 that small and medium enterprises should adapt to market dynamics [1], [2] since small and medium enterprises have significant role in the development of a country [3][4][5]. Industrial revolution 4.0 is indicated by rapid digitalization in various sectors [6], [7]. One of the indicators is digitalization which is integrated in production process that can enhance supply chain productivity so that efficiency is achieved [8][9][10].

Although digitalization may create efficiency, innovation, business growth, and competitive advantage [8], [11]; it emerges numerous challenges for small and medium enterprises [2], [10], [12]-[15]. This happens since small and medium enterprises do not optimally make use of Information and Communication Technology (ICT) like what large companies do [7], [11]. Economics education allows one to make better decision by considering cost and benefit. Thus, economics education is surely essential for both individual and society [16]. Unfortunately, not all ISSN: 2456-7620

https://dx.doi.org/10.22161/ijels.56.22 entrepreneurs study and get economics education.

Economic literacy is important for small and medium enterprises entrepreneurs particularly if it is related to digital world as one's improved economic literacy contributes to the society or the country [17]. Moreover, small and medium enterprises may have more chances to grow when economic literacy is combined with digital economic [10], [18]. Consequently, it fosters the economy of a country [15], [17], [19]-[22].

\section{LITERATURE REVIEW}

\subsection{Literature Review}

2.1.1. Economic Literacy and Digitalization

Literacy is fundamental for individual behavior [23]. One is considered to have economic literacy when he/she knows and relates an economic theory in logically making economic decision [24]. Better economic literacy that one has influences him/her in making financial decision [17]. Economic literacy nurtures cooperation through developed 
economic knowledge and skill [24]. Digitalization on small and medium enterprises supports business activities that raises efficiency, eases the entrepreneurs in reaching customers, and eases them in getting immediate feedback [25], [26]. There are three categories of digitalization as (1) digital technology which is defined as a digital transformation that makes use of ICT, (2) digital organization which is defined as a digital transformation that changes and creates new business models, and (3) digital social innovation which is defined as digital transformation that influences life aspects [27]. This research deeply discusses digital technology on small and medium enterprises.

\subsubsection{Innovation and Technological Advances}

Besides being a factor that strengthens business survival, innovation is vital to maintain small and medium enterprises competitiveness [2]. Entrepreneurs prevent wasting resources and optimize business activities to fulfill customer needs through innovation [28]. Technology has already been a part of business [29]. Moreover, one innovation involved in business activities is the use of social media [30].

The involvement of technology positively influences small and medium enterprises performances [21]. However, this research finding shows that the use of technology insignificantly influences digitalization. In the era of industrial revolution 4.0 , in order to survive, small and medium enterprises should be guided to involve technology so that they work efficiently in developing products and maintaining the quality of their products [8], [30]. Companies or small and medium enterprises that benefit technology to perform online transactions have better potency to survive rather than those which still make use of conventional marketing [4]. Nevertheless, the lack of knowledge, skill, and experience become one of challenges for small and medium enterprises to involve technology [7].

\subsubsection{Knowledge of economy}

The use of term 'knowledge' as an economics terminology is frequently questioned since initially economy is only has something to do with manufacturing products and providing services [31]. Conversely, currently, knowledge of economy has a crucial role because it helps individual to make decision especially if it is related to cost and benefit [16], [32]. Knowledge of economy grasped by individual cannot be measured by looking at what one studies and achieves in formal education [33]. Besides from formal education, knowledge of economy can be grasped through experiences on a daily basis [24]. Small and medium enterprises are required to improve performances and innovations so that they can compete and survive [34].

\subsubsection{Connectivity and Users}

The presence of internet as a part of ICT accelerates economic development of a country [35]. Small and medium enterprises may involve various media such as (1) social media: whatsapp, facebook, instagram, twitter, (2) personal or business website, (3) digital platform or market place: bukalapak, tokopedia, shopee, blibli.com, alibaba, and others to connect them to many parties related to their business activities. Better communication and service can be provided if small and medium enterprises involve social media (Bouwman et al., 2018). The availability of market place offered by third party eases and helps small and medium enterprises to transform and compete in the era of industrial revolution 4.0 [36]. Digital media allows online transactions, payments, and feedbacks [4].

Digitalization empowers entrepreneurs to immediately and effectively communicate with customers and suppliers [4]. Recently, technology allows customers and suppliers to inquire and complain to entrepreneurs so that customers' trust and satisfaction are preserved [4], [7]. It is needed for small and medium enterprises to improve their business by networking aimed to expand business opportunities, maintain positive relationship, and keep long-term relationship [28]. In addition, it is a fact that technology helps companies to innovate and find new market [29].

\subsection{Research objective}

This research aims to identify the digital economic literacy influences on entrepreneurs that manage small and medium enterprises in the era of industrial revolution 4.0 by using variables that are digitalization, connectivity, technological advances, users, knowledge of economy, and innovation. Based on that research objective; $(\mathrm{H} 1)$ the influence of connectivity on digitalization, (H2) the influence of technological advances on digitalization, (H3) the influence of users on digitalization, (H4) the influence of knowledge of economy on digitalization, and (H5) the influence of innovation on digitalization are identified.

\subsection{Research objective}

This research aims to identify the digital economic literacy influences on entrepreneurs that manage small and medium enterprises in the era of industrial revolution 4.0 by using variables that are digitalization, connectivity, technological advances, users, knowledge of economy, and innovation. Based on that research objective; (H1) the influence of connectivity on digitalization, (H2) the influence of technological advances on digitalization, (H3) the influence of users on digitalization, (H4) the influence 
of knowledge of economy on digitalization, and (H5) the influence of innovation on digitalization are identified.

\section{METHODOLOGY}

There were a total of 120 respondents that manage small and medium enterprises. 30 samples from each city (Surakarta, Sukoharjo, Karang Anyar, and Sragen) were involved. This research applied quantitative approach.

\subsection{Research instrument}

The instrument used in this research was a questionnaire consisting of 34 items that had been tested its validity and reliability by using Smart PLS 2.0 program. Every item represented variables of this research which were digitalization, connectivity, technological advances, users, knowledge of economy, and innovation. Likert Scale consisting of four responses as; (1) "strongly disagree", (2) "disagree", (3) "agree", and (4)"strongly agree" were employed.

\subsection{Data analysis}

The influences of the variables (connectivity, technological advances, users, knowledge of economy, and innovation) on digitalization were tested by analyzing the data through Smart PLS 2.0. The analysis involved measurement model (outer model) and structural model evaluation (inner model). Outer model evaluation was used to know the validity and reliability of the model while inner model was used to know the relation among variables studied. There were three main steps done in main testing. They were (1) convergent validity comprising factor loading or outer loading, average variance extraced (AVE), and communality as its parameters; (2) discriminant validity comprising cross loading, square root of AVE, and Latent Variable Correlation as its parameters; and (3) reliability comprising Cronbach's Alpha and Composite Reliability as its parameters. Meanwhile, inner model evaluation could be seen from the value of $\mathrm{R}$-square and path coefficients (mean, STDEV, and t-values).

\section{RESULT AND DISCUSSION}

Based on the data analysis; outer model evaluation, particularly on convergent validity phase, shows that the factor loading of connectivity, technological advances, users, knowledge of economy, innovation, and digitalization is >0,7. Besides, AVE and communality value are $>0,5$. Meanwhile, in the phase of discriminant validity, the value of cross loading on its own variable is higher rather than on other variables. Furthermore, the discriminant validity of the variable can be measured by comparing AVE square root and Latent Variable Correlation. The AVE value of connectivity as one of the variables is 0,584 and the root of AVE is 0,764. The AVE value of technological advances is 0,632 and the root of AVE is 0,795 . The AVE value of users is 0,674 and the root of AVE is 0,821. The AVE value of knowledge of economy is 0,643 and the root of AVE is 0,802. Related to another variable that is innovation, the AVE value of it is 0,665 and the root of AVE is 0,815 . The AVE value of the last variable, digitalization, is 0,650 and the root of AVE is 0,806. After being compared to the value of Latent Variable Correlation shown in Table 1; it is found that the root of AVE on each variable is higher than that of Latent Variable Correlation. The root of AVE on users is higher than the correlation value between users and other constructs. This finding is also revealed on other variables.

Table 1. The Value of Latent Variable Correlation

\begin{tabular}{ccccccc}
\hline & $\mathrm{C}$ & $\mathrm{D}$ & $\mathrm{I}$ & $\mathrm{KE}$ & $\mathrm{TA}$ & $\mathrm{U}$ \\
\hline $\mathrm{C}$ & 1 & & & & & \\
$\mathrm{D}$ & 0,695 & 1 & & & & \\
$\mathrm{I}$ & 0,681 & 0,685 & 1 & & & \\
$\mathrm{KE}$ & 0,666 & 0,590 & 0,682 & 1 & & \\
$\mathrm{TA}$ & 0,644 & 0,659 & 0,693 & 0,465 & 1 & \\
$\mathrm{U}$ & 0,550 & 0,649 & 0,720 & 0,509 & 0,659 & 1 \\
\hline
\end{tabular}

The value of composite reliability and cronbach's alpha are measured through reliability test (rule of thumb >0,7). The value of composite reliability and cronbach's alpha on digitalization are $0,928>0,7$ and $0,909>0,7$; on connectivity are $0,926>0,7$ and $0,910>0,7$; on innovation are 0,922>0,7 and 0,899>0,7; on knowledge of economy are $0,900>0,7$ and $0,861>0,7$; on technology advances are $0,872>0,7$ and $0,807>0,7$; and on users are 0,861>0,7 and $0,766>0,7$. It can be concluded that each variable is reliable.

After the requirement of outer model evaluation is conformed, inner model evaluation is done. Through boothstrapping method, the r-square value of digitalization $(0,621)$ is found. Based on the result, digitalization as one of the variables studied in this research is categorized as a strong variable. It means that it can be justified $62,1 \%$ by other variables that are, conectivity, technological advances, users, knowledge of economy, and innovation.

In order to verify the hypothesis, there should be beta coefficient value and the comparison result of $\mathrm{T}$-statistic and $t$-value obtained from the table of path coefficient value (mean, STDEV, t-values). The level of significance 
in this research is $5 \%$ so that the weight fits the standard which is 1,96 . The result of hypothesis testing showing the path between conectivity and digitalization reveals that beta coefficient is 0.299 while t-value is $2.074>1,96$. This proves that connectivity positively and significantly influences digitalization. Hence, the hypothesis (H1) is accepted. The result of hypothesis testing showing the path between innovation and digitalization reveals that beta coefficient is 0.114 while t-value is $1,026<1,96$. This indicates that innovation positively influences digitalization though the influence is insignificant. Thus, the hypothesis is $(\mathrm{H} 2)$ rejected. Similar with the influence of innovation on digitalization, the influence of knowledge of economy on digitalization is positive but insignificant since beta coefficient is 0.111 while t-value is $0,995<1,96$. Therefore, the hypothesis $(\mathrm{H} 3)$ is rejected. Related to the influence of technological advances on digitalization, beta coefficient is 0.189 while $t$-value is $1,479<1,96$. It denotes that technological advances positively but insignificantly influence digitalization so that the hypothesis $(\mathrm{H} 4)$ is rejected. The last hypothesis is related to the influence of users and digitalization. It is found that its beta coefficient is 0.220 while t-value is $2,498>1,96$. Thus, users has positive and significant influence on digitalization that the hypothesis (H5) is accepted.

\section{CONCLUSION}

In the era of industrial revolution 4.0, digital transformation reinforces the speed and efficiency. Furthermore, it develops business model and nurtures competitiveness of small and medium enterprises as well as improves customer experience [37]. Nonetheless, digitalization that offers numerous possibilities and benefits for small and medium enterprises [12] essentially is not fully managed by the entrepreneurs of small and medium enterprises yet. The weaknesses of small and medium enterprises in facing the era of industrial revolution 4.0 are the lack of fund, knowledge, and skill. The lacks force small and medium enterprises unable to adapt technology. This phenomenon causes small and medium enterprises to have worse performance than that of large company [7]. The finding shows that though connectivity and users have significant influence; innovation, technological advances, and knowledge of economy insignificantly influence small and medium enterprises.

The research conducted by Camilleri (2018) shows positive and significant influence of technological innovation, digital media used as a communication media, on the benefit obtained by small and medium enterprises.
Unfortunately, this research shows that innovation does not have significant influence. Even though there are many research showing the influences of technological innovation on small and medium enterprises, research on different countries may show different findings [29]. This is caused by the lack of small and medium enterprises technology mastery and the lack of rapid digital innovation adaptation [4]. Thus, support and knowledge are required so that small and medium enterprises can develop those skills effectively [8] and innovate.

Moreover, it is found that the involvement of technology has insignificant influence on digitalization so that it has minor influence on small and medium enterprises. Since the employees of many small and medium enterprises lack technology skills, they feel uncertain and demotivated to adopt digitalization [4]. Small and medium enterprises face significant problem when technology in the era of industrial revolution 4.0 should be involved [3], [8]. The absence of technology becomes crucial challenge for small and medium enterprises [7], [12]. Small and medium enterprises that do not employ information and communication technology are affected by many factors; lack of internet service provider, financial problem, lack of knowledge, costly employee training cost, and lack of government support [19]. Success can be achieved by small and medium enterprises once they have sufficient knowledge and skill to use digital technology [3]. Therefore, adapting technology that is rapidly developed is strongly needed for small and medium enterprises [34].

The entrepreneurs' economic literacy is still low. This is a result of the insignificant influence of the knowledge of economy on small and medium enterprises digitalization. Based on the research finding, knowledge of economy positively but insignificantly influences digitalization. Compared to companies, small and medium enterprises not only lack of resources and its limited market influence but also lack of knowledge and skill (Stankovska et al., 2016). Economic literacy can be improved through two ways (1) the first way is through economics education comprising general and broad population (formal education), and (2) the second way focuses on daily experiences [24]. Education and training are needed so that small and medium enterprises are able to make use of ICT. Government is expected to link small and medium enterprises with training institutes [19] so that they can compete in the era of industrial revolution 4.0 [36].

Even though innovation, technological advances, and knowledge of economy do not significantly influence small and medium enterprises digitalization; connectivity and users benefits small and medium enterprises significantly. This research finding is in line with Nuseir's 
(2018). It is found that small and medium enterprises digitalization through internet brings positive influence on business performance and customer relationship. The company image is strengthened, the communication is easy and effective, and the chance to get new market is greater. Furthermore, connectivity allows small and medium enterprises to communicate and reach customers fast and easily in a short time so that the profit increases [37].

Based on this research; small and medium enterprises strongly require digital orientation be it on the individual, organization, or business environment so that they can adopt the technology, develop the skills, and support individuals to take risk [9]. This research is limited on testing the factors influencing small and medium enterprises digitalization in the era of industrial revolution 4.0. The researchers suggest other researchers to develop certain model or design that nurture and improve entrepreneurs' economic literacy, especially those that manage small and medium enterprises. The researchers also expect the university to share the knowledge by developing and approaching nearby small and medium enterprises. It can be through assisting technology optimization for small and medium enterprises or through conducting training. The government should pay more attention on the needs of entrepreneurs managing small and medium enterprises that may have many flaws comparing to companies. To benefit technology in the digitalization era, supports and facilities from both private parties and universities are required since they ease small and medium enterprises to benefit technology.

\section{REFERENCES}

[1] C. T. Street, B. Gallupe, J. Baker, C. Street, and J. Baker, "Strategic Alignment in SMEs: Strengthening Theoretical Foundations Theoretical Foundations," Commun. Assoc. Inf. Syst., vol. 40, no. 20, pp. 420-442, 2017.

[2] J. Vrchota, T. Volek, and M. Novotna, "Factors Introducing Industry 4.0 to SMES," Soc. Sci., vol. 8, no. 5, p. 130, 2019.

[3] F. Lehner and M. W. Sundby, "ICT Skills and Competencies for SMEs: Results from a Structured Literature Analysis on the Individual Level," Impact Digit. Work., pp. 55-69, 2018.

[4] M. T. Nuseir, "Digital Media Impact on SMEs Performance in The UAE," Acad. Entrep. J., vol. 24, no. 2, pp. 1-13, 2018.

[5] O. G. Omiunu, "E-literacy-adoption model and performance of women-owned SMEs in Southwestern Nigeria," J. Glob. Entrep. Res., vol. 3, 2019.
[6] B. Barann, A. Hermann, and F. Chasin, "Supporting Digital Transformation in Small and Medium-sized Enterprises : A Procedure Model Involving Publicly Funded Support Units," Proc. 52nd Hawaii Int. Conf. Syst. Sci., vol. 6, no. 2, pp. 4977-4986, 2019.

[7] I. Stankovska, S. Josimovski, and C. Edwards, "Digital channels diminish SME barriers: the case of the UK," Econ. Res. Istraživanja, vol. 29, no. 1, pp. 1-16, 2016.

[8] C. Faller and D. Feldmüller, "Industry 4 . 0 Learning Factory for regional SMEs," Procedia Int. Acad. Prod. Eng., vol. 32, pp. 88-91, 2015.

[9] S. Quinton, A. Canhoto, S. Molinillo, and R. Pera, "Conceptualising a digital orientation: antecedents of supporting SME performance in the digital economy," $J$. Strateg. Mark., vol. 26, no. 5, pp. 1-13, 2017.

[10] A. Tarutè, J. Duobienè, L. Klovienė, E. Vitkauskaitè, and V. Varaniūtè, "Identifying Factors Affecting Digital Transformation of SMEs," Proc. 18th Int. Conf. Electron. Bus., pp. 373-381, 2018.

[11] D. Consoli, "Literature analysis on determinant factors and the impact of ICT in SMEs," Procedia-social Behav. Sci., vol. 62, pp. 93-97, 2012.

[12] J. Cenamor, V. Parida, and J. Wincent, "How entrepreneurial SMEs compete through digital platforms: The roles of digital platform capability, network capability and ambidexterity," J. Bus. Res., vol. 100, pp. 196-206, 2019.

[13] C. M. L. Chan, S. Y. Teoh, A. Yeow, and G. Pan, "Agility in responding to disruptive digital innovation: Case study of an SME Agility in responding to disruptive digital innovation: Case study of an SME," Inf. Syst. J., vol. 29, no. 2, pp. 436-455, 2018.

[14] D. Grube, A. A. Malik, and A. Bilberg, "SMEs can touch Industry 4.0 in the Smart Learning Factory," Procedia Manuf., vol. 31, pp. 219-224, 2019.

[15] Ö. Önday, "What Would Be the Impact of Industry 4 . 0 on SMEs : The Case of Germany," Int. J. Manag., vol. 7, no. 2, pp. 11-19, 2018.

[16] K. V Anthony, R. C. Smith, and N. C. Miller, "Preservice elementary teachers ' economic literacy: Closing gates to full implementation of the social studies curriculum," $J$. Soc. Stud. Res., vol. 39, no. 1, pp. 29-37, 2015.

[17] R. Yayar and Ö. E. A. Karaca, "Economic literacy levels of public officers in Turkey," Pakistan J. Commer. Soc. Sci., vol. 11, no. 1, pp. 49-65, 2017.

[18] N. Janaratne, "A framework for improving innovation capability of SMEs to enhance competitiveness in the digital economy," SEAANZ Conf. Proc., pp. 1-12, 2014.

[19] I. Apulu and E. O. Ige, "Are Nigeria SMEs Effectively Utilizing ICT?," Int. J. Bus. Manag., vol. 6, no. 6, pp. 207214, 2011.

[20] M. Khalique, A. H. M. Isa, and J. A. N. Shaari, 
"Challenges for Pakistani SMEs in a Knowledge-Based Economy," Indus J. Manag. Soc. Sci., vol. 5, no. 2, pp. 7480, 2011.

[21] J. B. Mabula, "Use of Technology and Financial Literacy on SMEs Practices and Performance in Developing Economies," Int. J. Adv. Comput. Sci. Appl., vol. 9, no. 6, pp. 74-82, 2018.

[22] L. Rezny, J. B. White, and P. Maresova, "The knowledge economy: Key to sustainable development?," Struct. Chang. Econ. Dyn., 2019.

[23] A. Di Girolamo, G. W. Harrison, M. I. Lau, and J. T. Swarthout, "Subjective belief distributions and the characterization of economic," J. Behav. Exp. Econ., vol. 59, pp. 1-12, 2015.

[24] S. Dilek, H. Kesgingoz, A. Konak, and S. Halicioglu, "Factors Affecting Economic Literacy," Afro Eurasian Stud., vol. 7, no. 1, pp. 11-51, 2018.

[25] H. Bouwman, S. Nikou, and M. De Reuver, "Digitalization , business models, and SMEs: How do business model innovation practices improve performance of digitalizing SMEs ?," Telecomm. Policy, no. October 2017, p. 101828 , 2019.

[26] C. A. De Souza, É. S. Siqueira, and N. Reinhard, "Digital Divide of Small and Meium-Sized Enterprises: An Analysis of Influencing Factors Using The TOE Theory," Rev. Adm. Mackenzie, vol. 18, no. 2, pp. 15-48, 2017.

[27] J. Reis, M. Amorim, N. Melao, and P. Matos, "Digital Transformation: A Literature Review and Guidelines for Future Digital Transformation: A Literature Review and Guidelines for Future Research," World Conf. Inf. Syst. Technol., no. May, pp. 411-421, 2018.

[28] A. Pierre and A. Fernandez, "Going Deeper Into SMEs Innovation Capacity: An Empirical Exploration Of Innovation Capacity," J. Innov. Econ. Manag., pp. 139$181,2018$.

[29] N. A. Rahman, Z. Yaacob, and R. M. Radzi, "An Overview of Technological Innovation on SME Survival: A Conceptual Paper," Procedia - Soc. Behav. Sci., vol. 224, pp. 508-515, 2016.

[30] H. Bouwman, S. Nikou, F. J. Molina-castillo, and M. De Reuver, "The impact of digitalization on business models," Digit. Policy, Regul. Gov., vol. 20, no. 2, pp. 105-124, 2018.

[31] A. S. Weber, "The role of education in knowledge economies in developing countries," Procedia - Soc. Behav. Sci., vol. 15, pp. 2589-2594, 2011.

[32] A. Lo Prete, "Inequality and the finance you know: does economic literacy matter?,” Econ. Polit., 2018.

[33] A. Lo Prete, "Economic literacy , inequality , and financial development," Econ. Lett., vol. 118, no. 1, pp. 74-76, 2013.

[34] J. M. Smith, L. Webster, J. M. Smith, and L. Webster, "The Knowledge Economy and SMEs: A Survey Of Skills
Requirements," Bus. Inf. Rev., vol. 17, no. 3, pp. 138-146, 2000.

[35] N. Friederici, S. Ojanperä, and M. Graham, "The Impact of Connectivity in Africa: Grand Visions and the Mirage of Inclusive Digital Development," Electron. J. Inf. Syst. Dev. Ctries., vol. 79, no. 1, pp. 1-20, 2017.

[36] L. Li, F. Su, W. Zhang, and J.-Y. Mao, "Digital transformation by SME entrepreneurs: A capability perspective,” Inf. Syst. J., vol. 28, no. 6, pp. 1-29, 2017.

[37] M. R. Faridi, P. Sattam, B. Abdulaziz, A. Malik, P. Sattam, and B. Abdulaziz, "Customer Engagement Technology In SMEs In Saudi Arabia: Does It Ensue In Disturbance Or Distrupstion," Int. J. Entrep., vol. 23, no. 1, pp. 1-8, 2019.

[38] M. Camilleri, "The SMEs ' Technology Acceptance of Digital Media for Stakeholder Engagement," J. Small Bus. Enterp. Dev., no. August, pp. 0-26, 2018. 